\title{
KRISTALINITAS DAN KEKERASAN BERAS ANALOG YANG DIHASILKAN DARI PROSES EKSTRUSI PANAS TEPUNG JAGUNG
}

\author{
[Crystallinity and Hardness of Rice Analogue Produced from Corn Flour through Hot \\ Extrusion Processes]
}

\author{
Faleh Setia Budi ${ }^{1,2) \star}$, Purwiyatno Hariyadi ${ }^{1,2)}$, Slamet Budijanto ${ }^{1,2)}$, dan Dahrul Syah ${ }^{1,2)}$ \\ 1) Departemen Ilmu dan Teknologi Pangan, Fakultas Teknologi Pertanian, Institut Pertanian Bogor, Bogor \\ 2) Southeast Asian Food and Agricultural Science and Tecnology Center, Institut Pertanian Bogor, Bogor
}

Diterima 18 April 2017 / Disetujui 05 Juni 2017

\begin{abstract}
Rice analogues are food products made from broken rice and/or any other carbohydrate sources to have similar texture and shape to those of rice. Corn flour can be used as a material to make the rice analogues because it has various amylose contents ranging from low, medium, and high so that it is possible to make the dough with different levels of amylose contents. High temperature extrusion process may change crystallinity of starch (crystal type of $A$ to $V$ and degree of crystallization). Changes in starch crystallinity may influence the physical properties of the rice analogue produced. This research aimed to assess the effect of flour amylose content and temperature of extrusion on the crystallinity and its impact on physical properties of rice analogue. High amylose corn starch and corn flour were mixed at certain ratios to ob tain amylose contents of $16.99,19.35,21.72$, and $24.09 \%$. The dough was made by adding water to the mixed flour to have a moisture content of $40 \%$. The dough was then extruded at tempe ratures of 70,80 , and $90^{\circ} \mathrm{C}$ using a twin screw extruder (BEX-DS-2256 Berto). The observed physical properties were type of crystal, degree of crystallinity, and hardness of the rice analogue. The results showed that the increase in extrusion temperatures from $70^{\circ} \mathrm{C}$ to $90^{\circ} \mathrm{C}$ increased the degree of crystallinity of the rice analogues from $7.98-11.49 \%$ to $12.15-13.61 \%$ and hardness from 4.06-4.91 $\mathrm{kg}$ to $4.74-8.20 \mathrm{~kg}$. The increase in amylose contents (from $16.99 \%$ to $24.09 \%$ ) enhanced the hardness of the rice analogue from 4.06-4.74 kg to 4.91-8.20 kg but did not show any significant effects on the degree of crystallinity. The degree of crystallinity is positively correlated with the hardness of rice analogue (correlation coefficient $r=0.8)$.
\end{abstract}

Keywords: corn flour, crystallinity, extrusion, hardness, rice analogue

\section{ABSTRAK}

Beras analog merupakan produk pangan yang dibuat dari beras patah dan/atau sumber karbohidrat lain yang dibuat menyerupai bentuk dan tekstur beras. Tepung jagung dapat digunakan sebaga i bahan untuk membuat beras analog karena memiliki kadar amilosa beragam dari rendah, medium, dan tinggi sehingga memungkinkan untuk membuat adonan dengan kadar amilosa yang bervariasi. Pengaplikasian suhu tinggi dari proses ekstrusi mengubah kristalinitas pati (tipe kristal $\mathrm{A}$ menjadi $\mathrm{V}$ dan derajat kristalinitas). Perubahan kristalinitas pati tersebut perlu diinvestigasi lebih lanjut karena diduga memengaruhi sifat-sifat fisik beras analog yang dihasilkan. Penelitian ini bertujuan untuk mengkaji pengaruh kadar amilosa tepung dan suhu ekstrusi terhadap perubahan kristalinitas tersebut dan dampaknya terhadap sifat-sifat fisik beras analog yang dihasilkan. Pati jagung berkadar amilosa tinggi dan tepung jagung dicampur dengan rasio tertentu untuk memperoleh tepung dengan kadar amilosa 16,99; 19,35; 21,72; dan 24,09\%. Adonan dibuat dengan menambahkan air ke campuran tepung untuk mendapatkan kadar air $40 \%$. Kemudian adonan tersebut diekstrusi pada suhu ekstrusi 70,80 , dan $90{ }^{\circ} \mathrm{C}$ menggunakan ekstruder ulir ganda (BEX-DS-2256 Berto). Sifat-sifat fisik yang diamati adalah tipe kristal, derajat kristalinitas dan kekerasan beras analog. Hasil penelitian menunjukkan bahwa peningkatan suhu ekstrusi dari $70^{\circ} \mathrm{C}$ sampai $90^{\circ} \mathrm{C}$ meningkatkan derajat kris talinitas dari 7,98-11,49\% menjadi 12,15-13,61\% dan kekerasan dari 4,06-4,91 kg menjadi 4,74-8,20 kg. Peningkatan kadar amilosa dari 16,99\% sampai $24,09 \%$ meningkatkan kekerasan beras analog dari 4,06-4,74 $\mathrm{kg}$ menjadi 4,91-8,20 kg tetapi tidak menunjukkan pengaruh yang nyata terhadap derajat kristalinitas. Derajat kristalinitas berkorelasi positif dengan kekerasan beras analog dengan nilai koefisien korelasi $r=0,8$.

Kata kunci: beras analog, ekstrusi, kekerasan, kristalinitas, tepung jagung 


\section{PENDAHULUAN}

Selama satu dekade terakhir, beras analog mendapatkan perhatian yang cukup besar dari beberapa negara di dunia seperti China, India, Indonesia, Philipina, dan Jepang. Beras analog dapat didefinisikan sebagai produk beras tiruan yang memiliki sifat-sifat yang mirip dengan beras dan dibuat dari beras patah maupun bahan pangan non beras (Machmur et al., 2011; Mishra et al., 2012). Pembuatan beras analog dari bahan pangan non beras dapat dimanfaatkan untuk mendukung program diversifikasi pangan suatu negara yang memiliki tingkat konsumsi beras yang tinggi dan tingkat konsumsi pangan non beras yang rendah (Budijanto dan Yuliyanti, 2012).

Sumber makanan pokok non beras yang meliputi jagung, sorghum, ubi jalar dan sebagainya dapat diekstrusi menjadi beras analog. Sumber makanan pokok non beras tersebut memiliki sifatsifat kimia dan fisik yang berbeda khususnya kandungan amilosanya (Wang et al., 2014). Perbedaan kandungan amilosa di dalam bahan dapat memengaruhi proses ekstrusi dan sifat-sifat beras analog yang dihasilkan. Hoan et al. (2010) mempelajari pengaruh kadar amilosa terhadap sifat-sifat fisik dan fungsional produk terekstrusi dan Xie et al. (2009) mengkaji sifat-sifat rheologi pati jagung dengan kadar amilosa yang berbeda. Jagung diminati untuk digunakan sebagai bahan karena jagung dengan kadar amilosa yang berbeda (rendah, medium dan tinggi) dapat diperoleh dari alam. Pati jagung berkadar amilosa tinggi digunakan untuk meningkatkan kadar amilosa tepung jagung sehingga dapat diperoleh tepung jagung simulasi dengan kadar amilosa yang berbeda tanpa merubah kristal tepung jagung yang bertipe A (Wang et al., 2014). Di samping itu jagung juga telah dikenal sebagai sumber makanan pokok di dunia, termasuk Indonesia.

Beberapa peneliti telah menggunakan teknologi ekstrusi untuk membuat beras analog dari bahan beras (Koide et al., 1999; Zhuang et al., 2010). Ekstrusi merupakan proses plastisasi bahan pangan yang mengandung pati dan atau protein di dalam pipa (barrel) dengan menggabungkan proses pencampuran, pemanasan, pemotongan mekanis (mechanical shearing) dan melewatkan die yang didesain untuk mendapatkan produk dengan bentuk tertentu (Budi et al., 2013). Sementara itu Budijanto et al. (2012) dan Budi et al. (2015a) telah membuat beras analog dari bahan campuran tepung jagungpati sagu dan tepung jagung-pati jagung dengan menggunakan teknologi ekstrusi panas. Namun ada permasalahan yang muncul dalam pembuatan beras analog, yaitu mudah hancurnya beras analog yang

*Penulis Korespondensi:

E-mail: phariyadi@ipb.ac.id dan faleh_sb01@yahoo.com dihasilkan ketika dikemas atau selama pengiriman dan penyimpanan di gudang yang disebabkan oleh tekanan saat beras analog terkemas ditumpuk selama pengiriman atau penyimpanan di gudang. Sifat fisik beras analog yang terkait dengan masalah ini adalah kekerasan yang merupakan parameter untuk mengukur kekuatan biji beras analog terhadap gaya yang menekannya atau dapat didefinisikan sebagai titik hancur beras analog (Ajeigbe et al., 2008). Kajian hubungan antara perubahan kristalinitas dan kekerasan sebagai fungsi dari kadar amilosa perlu dilakukan untuk mengatasi permasalahan tersebut.

Pada awalnya kekerasan beras analog diduga berkaitan dengan derajat gelatinisasi yang dicapai pada akhir proses. Koide et al. (1999) melaporkan bahwa pembuatan beras analog dengan teknologi ekstrusi pada kadar air $30-40 \%$ dan suhu ekstrusi $80^{\circ} \mathrm{C}$ menghasilkan beras analog dengan derajat gelatinisasi $50-60 \%$ dan pada suhu ekstrusi $120^{\circ} \mathrm{C}$ mencapai $90 \%$ atau lebih. Zhuang et al. (2010) juga melaporkan bahwa semakin tinggi suhu ekstrusi menyebabkan derajat gelatinisasi pati semakin tinggi. Namun penelitian Budi et al. (2015a) memberikan hasil yang berbeda dan menunjukkan bahwa proses ekstrusi panas pada suhu ekstrusi 70 $90^{\circ} \mathrm{C}$ dan kadar air adonan $35-45 \%$ telah menyebabkan granula pati tergelatinisasi sempurna dengan didukung data DSC dan mikroskop cahaya terpolarisasi karena perbedaan pada tahap penambahan air yang lebih awal dilakukan pada adonan umpan. Pengukuran derajat gelatinisasi dengan DSC berdasarkan perubahan enthalpy gelatinisasi pada bahan pati sebelum dan sesudah ekstrusi dan dengan mikroskop cahaya terpolarisasi berdasarkan perubahan jumlah granula pati yang masih menunjukkan birefringence sebelum dan sesudah proses ekstrusi telah mengoreksi kelemahan metode spektrofotometer Koide et al. (1999). Temuan Budi et al. (2015a) di dukung Liu et al. (2009) yang menyatakan bahwa prosess pemanasan dan pemotongan mekanis (mechanical shearing) pada proses ekstrusi telah menyebabkan terjadinya perusakan granula pati dan molekul amilopektin. Di samping itu beras analog yang dihasilkan juga memiliki tipe kristal $\mathrm{V}$ akibat terbentuknya senyawa kompleks amilosalipid. Perubahan kristalinitas beras analog selama proses ekstrusi memengaruhi sifat-sifat fisik beras analog yang dihasilkan. Penelitian beras analog dari bahan tepung dan pati jagung serta fokus kajian perubahan kristalinitas tersebut dan pengaruhnya terhadap kekerasan beras analog belum ada yang melakukan sebelumnya. Oleh karena itu penelitian ini bertujuan untuk mempelajari pengaruh kadar amilosa adonan berbahan jagung dan suhu ekstrusi terhadap kristalinitas beras analog dan sifat fisik beras analog. 


\section{BAHAN DAN METODE}

\section{Bahan}

Bahan yang digunakan dalam pembuatan beras analog terdiri dari tepung jagung (PT. Matahari Corn Mill, Indonesia), pati jagung ( $\mathrm{Pd}$. Anugerah, Indonesia), gliserol monostearat (GMS) (Dimodan HP-M, Danisco Sdn Bhd, Malaysia), dan air. Tepung jagung dan pati jagung dikarakterisasi dengan menganalisis kadar air (AOAC Metode 925.10), kadar abu (AOAC Metode 923.03), kadar lemak (AOAC Metodfe 920.39), dan kadar protein (AOAC Metode 960.52) (AOAC, 2009). Kadar total karbohidrat tepung dan pati jagung dihitung dengan metode by difference. Kadar pati total dari tepung dan pati jagung ditentukan dengan metode colorimetry menggunakan senyawa anthrone setelah dilakukan ekstrasi dan hidrolisa menjadi glukosa (Kang et al., 2017). Kadar amilosa ditentukan dengan Metode Spektrofotometer (Mahmood et al., 2007). Semua analisa kimia bahan diulang dua kali dan hasilnya ditampilkan sebagai nilai rata-rata \pm standar deviasi.

\section{Metode}

Pati jagung dan tepung jagung dicampur dengan rasio 10/90, 20/80, 30/70, dan 40/60 (w/w) di dalam mixer (HD Mixer, PT. Bertindomas Ciptasatya, Indonesia) untuk mendapatkan adonan dengan kadar amilosa 16,99; 19,35; 21,72; dan 24,09\%; kemudian ditambah dengan gliserol monostearate (Dimodan HP-M, Danisco Sdn Bhd, Malaysia) sebanyak $2 \%$. Air ditambahkan secara bertahap ke adonan sampai kadar airnya mencapai $40 \%$. Setelah homogen adonan dibiarkan selama 2 jam di dalam kemasan plastik. Selanjutnya adonan dimasukkan ke dalam hopper untuk diumpankan ke dalam ekstruder ulir ganda (Berto BEX-DS-2256, PT. Bertindomas Ciptasatya, Indonesia). Setelah suhu barrel mencapai 70,80 , dan $90^{\circ} \mathrm{C}$ dan kecepatan putar ulir $75 \mathrm{rpm}$, auger dioperasikan dengan kecepatan $30 \mathrm{rpm}$ untuk mengalirkan adonan dengan laju 26,4 kg basis kering/jam. Ekstrudat yang keluar dari die dipotong dengan pisau pada kecepatan putar tertentu. Setelah proses tunak (steady) dan menghasilkan ekstrudat yang baik, produk diambil dan dikeringkan dengan tray drier (ND4-60SP, Terada Seisakusho Co. Ltd., Jepang) pada suhu $60^{\circ} \mathrm{C}$ selama 3 jam. Sampel ekstrudat yang sudah kering dikumpulkan dan dianalisis sifatsifat fisiknya.

Setiap perlakuan diulang dua kali dan percobaan dirancang menggunakan rancangan acak lengkap faktorial (RAL faktorial). Variabel-variabel yang dipilih sebagai faktor percobaan adalah suhu ekstrusi pada level 70,80 , dan $90^{\circ} \mathrm{C}$ dan kadar amilosa adonan pada level 16,99; 19,35; 21,72; dan 24,09\%.
Parameter-parameter yang diamati antara lain: derajat kristalinitas dengan XRD, kekerasan, karakteristik panas dengan DSC, dan mikrostruktur beras analog dengan SEM.

\section{Difraksi sinar X (XRD)}

Sampel beras analog dihaluskan menjadi tepung dan ditempatkan pada wadah sampel khusus dari alumunium untuk dipapar sinar $\mathrm{X}$ monokromatik radiasi $\mathrm{Cu}-\mathrm{Ka}(\lambda=1,54 \mathrm{~A})$ yang dihasilkan oleh $X$ Ray Diffraction (XRD 7000 maxima $X$ Shimadzu Ltd., Jepang) di Laboratorium Masyarakat Nano Indonesia Puspitek Serpong. Sudut refleksi pemindaian $5-30^{\circ}$ dengan peningkatan $0,02^{\circ}$ (Shih et al., 2007). Difraktogram sinar $X$ yang diperoleh didekonvolusi dengan menggunakan software Origin 8.0 dan derajat kristalinitas (DK) dihitung dengan metode curve fitting menggunakan persamaan berikut:

$\mathrm{DK}=\mathrm{Ak} /$ At $\times 100 \%$

Ak adalah luas daerah kurva kristal dan At merupakan luas daerah kurva total (kristal + amorf) (Terinte et al., 2011). Pengukuran derajat kristalinitas diulang dua kali untuk setiap sampel.

\section{Differential scanning calorimetry}

Beras analog dihaluskan menjadi tepung dan ditimbang $3 \mathrm{mg}$ di dalam wadah sampel khusus (pan cell no. 201-53090). Sepuluh mikroliter akuades ditambahkan dengan mikropipet dan kemudian pan cell ditutup rapat hingga kedap. Pan cell yang berisi sampel dan akuades dibiarkan selama 2 jam pada suhu ruang untuk mencapai kesetimbangan dan kemudian dianalisis dengan memanaskannya menggunakan Differential Scanning Calorimeters (DSC 60 Shimadzu, Jepang) di Laboratorium Rekayasa Proses Pangan, Institut Pertanian Bogor dari suhu $40-120^{\circ} \mathrm{C}$ dengan laju pemanasan $5^{\circ} \mathrm{C} /$ menit (Gelders et al., 2004).

\section{Kekerasan beras analog}

Kekerasan beras analog yang dihasilkan diukur dengan alat Hardness Tester (Kiya Seisaku Shd. Ltd., Jepang). Pengukuran dilakukan sebanyak 30 kali. Sebutir beras analog ditempatkan di meja sampel. Jarum hitam dan jarum merah diatur berimpit dan menunjuk angka 0 dengan posisi jarum merah berada di sebelah kanan jarum hitam. Roda penekan diputar ke kanan agar turun dan menekan beras analog. Jika beras analog yang ditekan pecah, hentikan pemutaran roda penekan. Hasil pengukuran dibaca dengan melihat posisi jarum merah yang menunjuk ke angka tertentu (Ajeigbe et al., 2008). Data disajikan sebagai rata-rata \pm standar deviasi. 


\section{Mikrostruktur beras analog}

Sampel beras analog dipotong melintang dan ditempatkan pada dudukan sampel. Potongan sampel yang telah dilapisi logam Au ditempatkan pada lokasi sampel di dalam alat Scanning Electron Microscope SEM (Jeol JSM-5310 LV, Jepang) di Laboratorium Zoologi LIPI Biologi Cibinong dan tabung divakumkan $(0 \mathrm{~Pa})$. Perbesaran yang digunakan adalah 750x dan jika sudah mendapatkan gambar yang baik, dilakukan penyimpanan gambar dalam bentuk file (Budi et al., 2015b).

\section{Analisis statistik}

Analisis statistik dilakukan menggunakan Program SPSS 20 (SPSS Inc., Chicago, IL, USA). Hasil yang diperoleh dalam penelitian dinyatakan sebagai nilai rata-rata dari beberapa ulangan \pm standard deviasi. Analisa varian yang dihasilkan oleh pengolahan data dengan Program SPSS 20 digunakan untuk mengevaluasi pengaruh faktorfaktor percobaan. Jika faktor mempunyai nilai signifikansi $\alpha<0,05$ maka faktor mempunyai pengaruh yang signifikan terhadap respon. Faktor-faktor percobaan yang memiliki pengaruh signifikan terhadap hasil percobaan dilakukan Duncan Multiple Range Test (DMRT) (pada level $P=0,05$ ) untuk mengetahui perbedaan hasil percobaan pada beberapa level faktor percobaan tersebut. Koefisien korelasi pearson digunakan untuk menentukan hubungan antara derajat kristalinitas dan kekerasan beras analog.

\section{HASIL DAN PEMBAHASAN}

\section{Karakteristik bahan (tepung dan pati jagung)}

Perbandingan komposisi kimia tepung jagung terhadap pati jagung menunjukkan bahwa tepung jagung mengandung protein $1,720 \%$ dan lemak $595 \%$ dari komposisi pati jagung, sedangkan kadar karbohidrat tepung jagung $89,37 \%$ dari karbohidrat pati jagung (Tabel 1). Tepung jagung mengandung amilosa $38,18 \%$ dan pati $82,09 \%$ dari kadar amilosa dan pati dalam pati jagung. Namun kadar serat tepung jagung 1,829\% dari kadar serat pati jagung (Tabel 2). Tepung jagung dan pati jagung diperoleh dari perusahaan yang berbeda. Perbedaan komposisi kimia dapat disebabkan oleh tipe/varitas jagung dan proses pengolahannya. Setiap varitas jagung mempunyai komposisi kimia yang spesifik yang dipengaruhi oleh cuaca, tanah, pupuk dan sebagainya. Tepung jagung diproses dengan menggiling endosperm jagung kering (grits) sehingga semua komponen yang ada di dalam endosperm akan berada di dalam tepung jagung (Gragasin dan Martinez, 2015). Pati jagung diekstrak dari jagung yang telah direndam dengan menggunakan air dan digiling dan kemudian dikeringkan sehingga kom- ponen pati akan menjadi sangat dominan di dalam produk pati jagung (Eckhoff dan Watson, 2009).

Tabel 1. Hasil analisis proksimat tepung dan pati jagung

\begin{tabular}{lcc}
\hline \multicolumn{1}{c}{ Parameter } & Tepung Jagung & Pati Jagung \\
\hline Kadar air $(\%)$ & $12,29 \pm 0,02$ & $12,04 \pm 0,05$ \\
Kadar abu (\%) & $0,67 \pm 0,01$ & $0,09 \pm 0,01$ \\
Lemak (\%) & $1,19 \pm 0,08$ & $0,20 \pm 0,02$ \\
Protein (\%) & $7,91 \pm 0,07$ & $0,46 \pm 0,02$ \\
Karbohidrat (\%) & $77,94 \pm 0,17$ & $87,21 \pm 0,03$ \\
\hline Sumber: Budi et al. (2015a)
\end{tabular}

Tabel 2. Kadar pati, amilosa dan serat dari tepung dan pati jagung

\begin{tabular}{lcc}
\hline \multicolumn{1}{c}{ Parameter } & Tepung Jagung & Pati Jagung \\
\hline Pati $(\%)$ & $71,20 \pm 2,14$ & $86,73 \pm 2,81$ \\
Amilosa (\%) & $14,62 \pm 0,13$ & $38,29 \pm 0,34$ \\
Serat $(\%)$ & $5,93 \pm 0,06$ & $0,46 \pm 0,07$ \\
\hline
\end{tabular}

Sumber: Budi et al. (2015a)

Difraktogram sinar $X$ menunjukkan bahwa tepung dan pati jagung keduanya mempunyai tipe kristal yang sama yaitu tipe kristal $A$ yang ditandai dengan adanya peak-peak pada sudut refleksi $2 \theta$ : 15, 17, 18 dan $23^{\circ}$. Namun demikian derajat kristalinitas pati jagung $(29,08 \%)$ lebih rendah dibanding derajat kristalinits tepung jagung (32,75\%). Perbedaan tersebut disebabkan oleh kadar amilosa pati jagung yang lebih tinggi (38,29\%) daripada tepung jagung $(14,62 \%)$. Komponen amilosa tidak terlibat dalam pembentukan kristal di dalam granula pati yang terbentuk dari struktur double helice rantai cabang molekul amilopektin (Alcazar-Alay dan Meireles, 2015). Kibar et al. (2010) yang melakukan studi gelatinisasi pati jagung pada berbagai kadar amilosa melaporkan bahwa pati jagung dengan kadar amilosa rendah sampai sedang memiliki tipe kristal A dan pati jagung berkadar amilosa tinggi mempunyai tipe kristal B tetapi tidak ada korelasi yang teramati antara derajat kristalinitas dan kadar amilosa pati jagung.

\section{Tipe kristal dan derajat kristalinitas beras analog}

Proses ekstrusi pembuatan beras analog pada berbagai perlakuan percobaan (suhu ekstrusi 70, $80,90^{\circ} \mathrm{C}$ dan kadar amilosa 16,$99 ; 19,35 ; 21,72$; dan $24,09 \%$ ) telah mengubah bentuk tipe kristal bahan tepung jagung dari $\mathrm{A}$ menjadi $\mathrm{V}$ yang ditandai dengan bergesernya peak kurva kromatogram dari $15,17,18$, dan $23^{\circ}$ menjadi 7,13 , dan $20^{\circ}$ (Gambar 1). Perubahan bentuk tipe kristal tersebut dapat disebabkan oleh pembentukan senyawa kompleks amilosa-lipid pada saat proses ekstrusi. Pembentukan senyawa kompleks amilosa-lipid juga dilaporkan Frost et al. (2009) yang mengekstrusi pati jagung pada suhu $60-100^{\circ} \mathrm{C}$. Jadi, tipe kristal beras analog sangat berbeda dari beras kontrol IR 64 yang 
memiliki tipe kristal $A$, sama seperti tepung jagung karena keduanya termasuk golongan serealia.

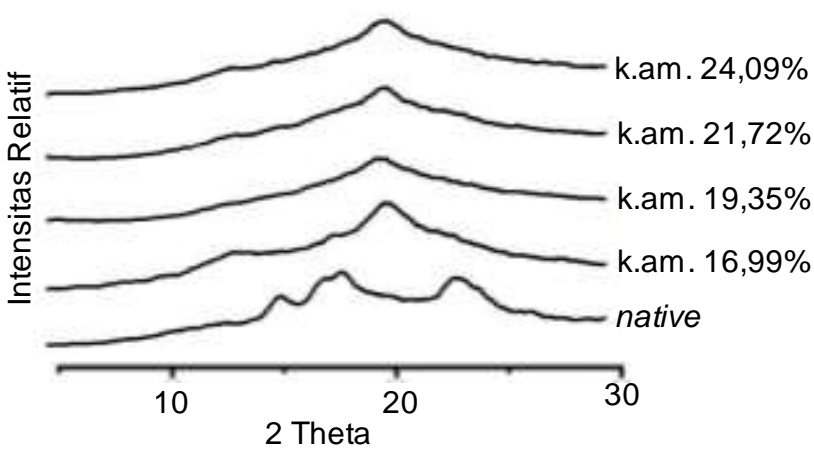

Gambar 1. Difraktogram XRD tepung jagung dan beras analog yang diproduksi pada suhu ekstrusi $80^{\circ} \mathrm{C}$ dan kadar air $40 \%$ (k.am.: kadar amilosa)

Pengaruh suhu ekstrusi dan kadar amilosa adonan terhadap derajat kristalinitas ditampilkan pada Gambar 2. Kedua faktor cenderung meningkatkan derajat kristalinitas beras analog. Namun analisis statitik (sidik ragam pada taraf uji $P=0,05$ ) menunjukkan bahwa hanya perlakuan suhu ekstrusi yang memberikan pengaruh secara signifikan terhadap derajat kristalinitas beras analog yang dihasilkan. Faktor kadar amilosa adonan dan interaksi antara suhu ekstrusi-kadar amilosa adonan tidak memberikan pengaruh yang signifikan terhadap derajat kristalinitas beras analog.

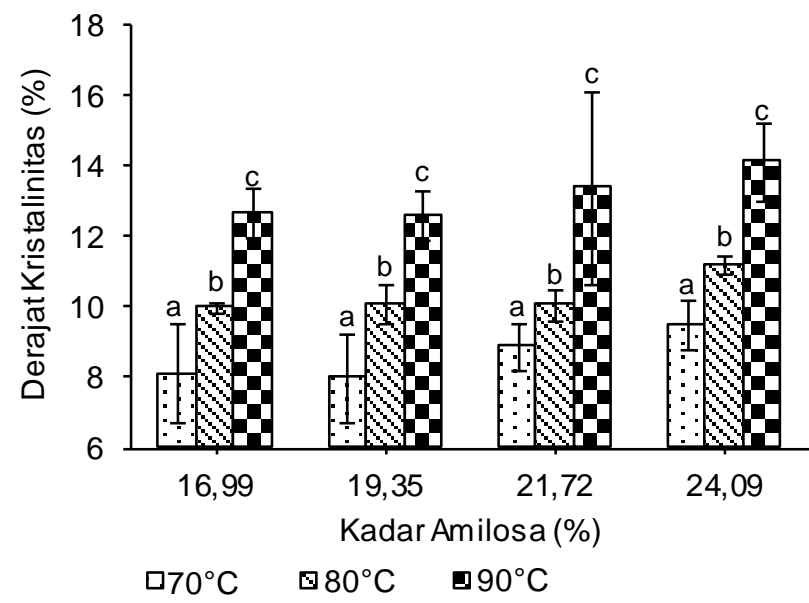

Gambar 2. Grafik hubungan derajat kristalinitas (DK) dan kadar amilosa adonan pada suhu ekstrusi 70,80 , dan $90^{\circ} \mathrm{C}$. Huruf yang berbeda di ujung luar kolom menunjukkan adanya perbedaan yang nyata pada taraf uji $P=0,05$

Peningkatan suhu ekstrusi dari $70^{\circ} \mathrm{C}$ sampai $90^{\circ} \mathrm{C}$ telah meningkatkan derajat kristalinitas beras analog sekitar 1,4 kali (dari 7,98-11,49\% menjadi $12,15-13,61 \%$ ). Hal ini menunjukkan bahwa molekul -molekul senyawa kompleks amilosa-lipid yang terbentuk tersusun semakin teratur dengan meningkatnya suhu ekstrusi. Energi dari peningkatan suhu ekstrusi dapat mendorong rekonstruksi senyawa kompleks amilosa-lipid yang tersusun secara acak menjadi lebih teratur. Hasil analisis uji lanjut DMRT pada level $P=0,05$ menunjukan bahwa perlakuan suhu ekstrusi 70,80 , dan $90^{\circ} \mathrm{C}$ menghasilkan beras analog dengan derajat kristalinitas yang berbeda nyata. Namun derajat kristalinitas beras analog pada suhu esktrusi $70^{\circ} \mathrm{C}$ relatif mirip dengan pola kristalinitas pada suhu ekstrusi $80^{\circ} \mathrm{C}$ tetapi derajat kristalinitas keduanya berbeda cukup jauh dengan suhu ekstrusi $90^{\circ} \mathrm{C}$. Cuthbert et al. (2012) juga membahas peningkatan derajat kristalinitas ekstrudat (hasil proses ekstrusi) akibat pembentukan senyawa kompleks amilosa-lipid tipe I dan II sebagai dampak dari peningkatan suhu proses ekstrusi. Hasil analisis DSC pada Gambar 3 memperlihatkan bahwa beras analog yang diperoleh pada suhu ekstrusi 70 dan $80^{\circ} \mathrm{C}$ mempunyai suhu/ titik leleh $(\mathrm{Tm}) 96^{\circ} \mathrm{C}$ dan beras analog yang diperoleh pada suhu ekstrusi $90^{\circ} \mathrm{C}$ memiliki titik leleh (Tm) $113^{\circ} \mathrm{C}$. Menurut Gelders et al. (2004), titik leleh $96^{\circ} \mathrm{C}$ merupakan suhu leleh dari senyawa kompleks amilosa-lipid tipe I yang dibentuk dari reaksi amilosa rantai pendek dengan lipid (GMS).

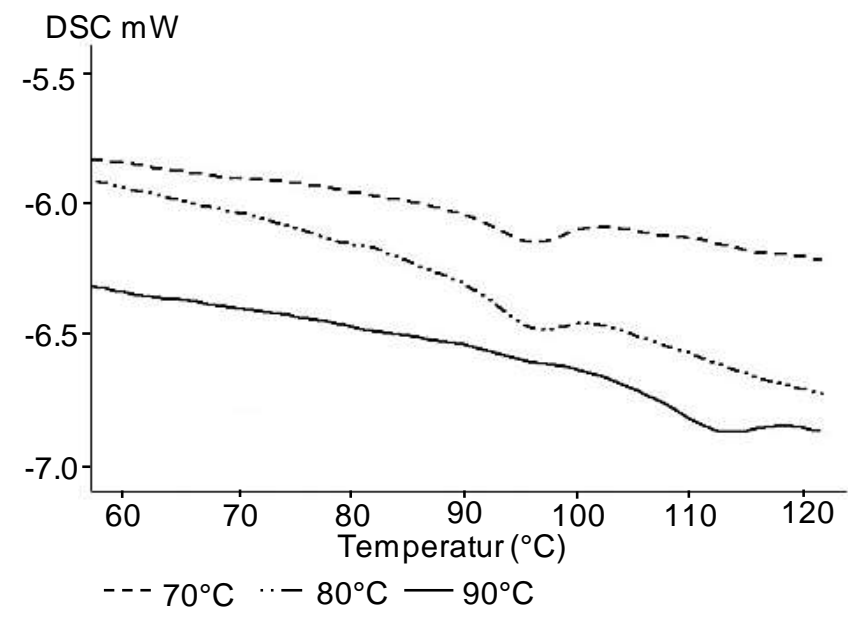

Gambar 3. Termogram DSC beras analog dari adonan dengan kadar amilosa 16,99\% dan kadar air $40 \%$ pada suhu ekstrusi 70 , 80, dan $90^{\circ} \mathrm{C}$. Sumber: Budi et al. (2015b)

Kristal senyawa kompleks amilosa-lipid tipe I terbentuk melalui pembentukan inti yang cepat pada suhu ekstrusi kurang dari atau sama dengan $80^{\circ} \mathrm{C}$, yang menyebabkan helice senyawa kompleks amilosa lipid terdistribusi secara acak, sedangkan titik leleh $113^{\circ} \mathrm{C}$ adalah suhu leleh dari senyawa kompleks amilosa-lipid tipe II yang merupakan hasil reaksi dari amilosa rantai panjang dengan GMS. Senyawa kompleks amilosa-lipid tipe II yang tersusun dari 
amilosa rantai panjang memiliki kemampuan untuk mengorganisasikan molekul membentuk struktur yang lebih teratur (Gelders et al., 2004). Beras IR 64 yang menjadi kontrol mempunyai derajat kristalinitas $33,63 \%$ lebih tinggi dibanding beras analog. Kristalinitas beras IR 64 berasal dari rantai cabangrantai cabang amilopektin yang membentuk double helice dan terususun sejajar dalam tumpukan yang teratur atau Kristal (Alcazar-Alay dan Meireles, 2015).

\section{Kekerasan beras analog}

Pengaruh suhu ekstrusi dan kadar amilosa adonan terhadap kekerasan beras analog ditampilkan pada Gambar 4. Seperti derajat kristalinitas, kedua faktor cenderung meningkatkan kekerasan beras analog. Analisis statistik (uji anova pada taraf $P=0,05)$ memperlihatkan bahwa perlakuan suhu ekstrusi, kadar amilosa adonan, dan interaksi antara suhu ekstrusi-kadar amilosa adonan memberikan pengaruh yang signifikan terhadap kekerasan beras analog.

Peningkatan suhu ekstrusi dari $70^{\circ} \mathrm{C}$ menjadi $90^{\circ} \mathrm{C}$ telah meningkatkan kekerasan beras analog sekitar 1,5 kali (dari 4,06-4,91 kg menjadi 4,74-8,20 $\mathrm{kg}$ ). Hasil uji lanjut DMRT pada level $P=0,05$ menunjukkan bahwa kekerasan beras analog pada perlakuan suhu ekstrusi 70,80 , dan $90^{\circ} \mathrm{C}$ tampak berbeda nyata. Peningkatan kekerasan ini disebabkan oleh peningkatan derajat kristalinitas beras analog. Semakin tinggi derajat kristalinitas beras analog maka semakin teratur susunan molekul senyawa kompleks amilosa-lipid sehingga gaya antar molekul menjadi semakin kuat. Terutama pada suhu ekstrusi $90^{\circ} \mathrm{C}$, senyawa kompleks amilosa-lipid tipe II yang tersusun dari molekul amilosa rantai panjang terbentuk dan memiliki derajat kristalinitas yang lebih tinggi dibanding derajat kristalinitas senyawa kompleks amilosa-lipid tipe I yang terbentuk pada suhu ekstrusi kurang dari atau sama dengan $80^{\circ} \mathrm{C}$ dari molekul amilosa rantai pendek. Hal ini berdampak pada jumlah energi yang dibutuhkan untuk memutuskan ikatan tersebut atau untuk merusak beras analog tersebut semakin besar, yang berarti bahwa beras analog tersebut semakin keras. De Pilli et al. (2011) juga melaporkan bahwa kekerasan atau kekuatan ekstrudat semakin meningkat seiring dengan peningkatan suhu ekstrusi dari $72^{\circ} \mathrm{C}$ sampai $128^{\circ} \mathrm{C}$. Peningkatan kekerasan beras analog akibat peningkatan suhu ekstrusi juga didukung oleh mikrostruktur beras analog dengan menggunakan SEM. Hasil foto SEM potongan melintang beras analog pada suhu ekstrusi $70^{\circ} \mathrm{C}$ menunjukkan bahwa ada beberapa granula pati telah mengalami pembengkakan (swelling) karena tergelatinisasi tetapi belum terdisintegrasi (break down) sehingga masih tampak utuh (intact). Namun ada juga beberapa granula yang telah rusak karena tergelatinisasi dan kemudian teretrogradasi. Beberapa swollen granule tampak ada yang bebas tidak berinteraksi dan ada beberapa yang menempel satu sama lain dan tidak terikat kuat (Gambar 5A). Oleh karena itu ikatanikatan antar partikel beras analog tersebut mudah dipatahkan dan beras menjadi rapuh atau mudah pecah. Pada suhu ekstrusi $80^{\circ} \mathrm{C}$, granula-granula pati sudah tidak tampak dan telah mengalami kerusakan (break down). Partikel-partikel pecahan dari granula yang telah rusak tersebut belum menyatu sepenuhnya dan sedikit terikat (Gambar 5B). Ikatan antar partikel yang muncul di dalam butiran beras analog sedikit meningkatkan kekuatan beras analog. Pada suhu ekstrusi $90^{\circ} \mathrm{C}$, partikelpartikel pecahan granula sudah tidak terlihat dan tampak menyatu sehingga terbentuk ikatan sempurna dan meningkatkan kekuatan butiran beras analog (Gambar 5C). Peningkatan suhu ekstrusi meningkatkan jumlah ikatan antar partikel sehingga meningkatkan kekerasan butiran beras analog.

Perlakuan peningkatan kadar amilosa di dalam adonan meningkatkan kekerasan butiran beras analog sekitar 1,4 kali (dari 4,06-4,74 kg menjadi 4,91-8,20 kg). Komponen amilosa yang tidak terkonversi menjadi senyawa kompleks amilosa lipid merupakan senyawa amilosa bebas yang akan berfungsi sebagai pengikat molekul-molekul amilopektin terdegradasi atau partikel-partikel beras analog (Verma et al., 2013).

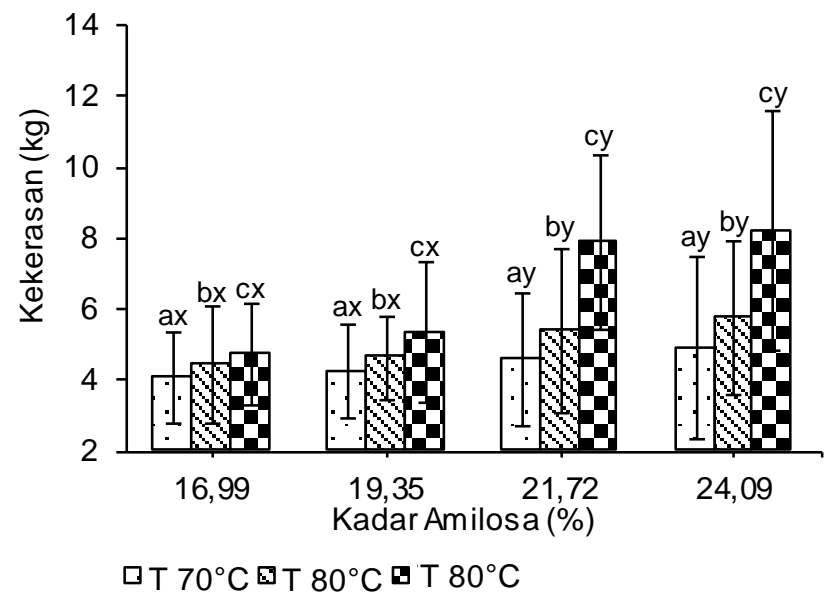

Gambar 4. Grafik hubungan kekerasan beras analog dan kadar amilosa adonan pada suhu ekstrusi 70,80 , dan $90^{\circ} \mathrm{C}$. Huruf yang berbeda di ujung luar kolom menunjukkan adanya perbedaan yang nyata pada taraf uji $P=0,05$. Huruf a, b, $c$ untuk faktor suhu ekstrusi dan huruf $x$, y untuk faktor kadar amilosa

Peningkatan kadar amilosa akan mendorong pembentukan ikatan network antar molekul-molekul amilopektin terdegradasi semain intensif sehingga akan meningkatkan kekuatan atau kekerasan beras 
analog. Analisa statistik dengan menggunakan uji lanjut DMRT pada level $P=0,05$ menunjukkan bahwa kekerasan beras analog pada kadar amilosa 16,99 dan $19,35 \%$ tidak berbeda nyata tetapi kekerasan beras analog pada kadar amilosa 19,35 dan 21,72\% berbeda nyata. Kekerasaan beras analog pada kadar amilosa 21,72 dan 24,09\% juga tidak berbeda nyata. Jadi, peningkatan kadar amilosa adonan dari $16,99 \%$ menjadi $19,35 \%$ tidak mampu meningkatkan kekerasan beras analog secara signifikan. Ketika kadar amilosa mencapai 21,72\%, kekerasan beras analog yang dihasilkan meningkat signifikan. Singh et al. (2005) yang membandingkan sifat-sifat kimia fisik beras sosoh dari berbagai varitas melaporkan bahwa kadar amilosa mempunyai korelasi positif yang sangat kuat terhadap kekerasan beras sosoh (kristalin alami).

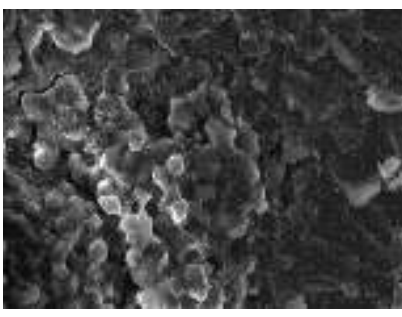

A

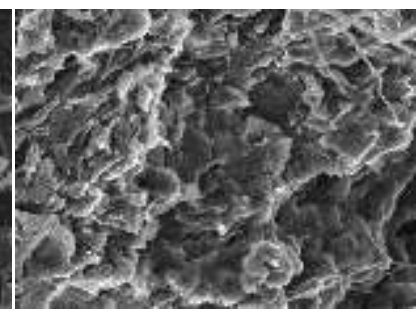

B

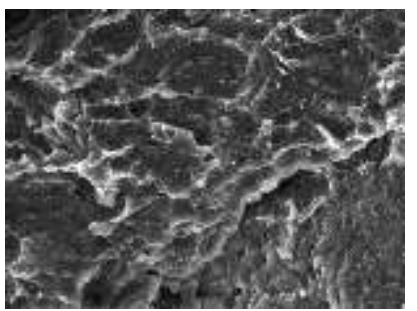

C

Gambar 5. Mikroskopi beras analog (potongan melintang) dengan kadar amilosa $16,99 \%$ dan suhu ekstrusi $70^{\circ} \mathrm{C}(\mathrm{A}), 80^{\circ} \mathrm{C}(\mathrm{B})$ dan $90^{\circ} \mathrm{C}(\mathrm{C})$ pada Pengamatan SEM dengan perbesaran $750 x$. Sumber: Budi et al. (2015b)

Kadar amilosa yang tinggi dapat memberikan ikatan yang lebih banyak antar partikel-partikel dan molekul-molekul sehingga beras cenderung keras. Namun hasil yang berkebalikan diperoleh oleh Thachil et al. (2014) yang mengekstrusi tepung jagung dengan kadar amilosa $25 \%$ dan $45 \%$ pada suhu ekstrusi $105^{\circ} \mathrm{C}$, kecepatan screw $350 \mathrm{rpm}$ dan kadar air 18\%. Ekstrudat jagung berkadar amilosa tinggi menunjukkan sifat kurang keras dibandingkan dengan ekstrudat jagung berkadar amilosa rendah. Jagung berkadar amilosa tinggi yang diekstrusi menghasilkan ekstrudat (tidak alami) yang lebih mengembang dan berpori sehingga ekstrudat menjadi mudah hancur (rapuh).
Kontribusi peningkatan kadar amilosa adonan terhadap kekerasan beras analog dapat juga dilihat dari mikrostruktur beras analog menggunakan SEM. Pada foto SEM beras analog dengan kadar amilosa 16,99\% (Gambar 6A) menunjukkan bahwa ada beberapa granula pati telah mengalami pembengkakan (swelling) karena tergelatinisasi tetapi belum terdisintegrasi (break down) sehingga masih terlihat utuh. Namun ada juga beberapa granula yang telah rusak karena tergelatinisasi dan kemudian teretrogradasi. Beberapa swollen granule tampak ada yang bebas tidak berinteraksi dan ada beberapa yang menempel satu sama lain dan tidak terikat kuat. Oleh karena itu ikatan-ikatan antar partikel beras analog tersebut mudah dipatahkan dan beras menjadi rapuh.

Sementara itu pada foto SEM beras analog dengan kadar amilosa 24,09\% (Gambar 6B), ada sebagian granula yang mengalami pembengkakan (swelling) dan belum terdisintegrasi sehingga masih terlihat. Namun ada sebagian lain granula pati telah mengalami kerusakan karena tergelatinisasi dan partikel-partikel pecahan granula tersebut terpilin dan terikat setelah teretrogradasi. Keberadaan ikatan-ikatan antar partikel ini menyebabkan peningkatan kekerasan beras analog. Pada Gambar 5B partikel-partikel pecahan granula tidak terpilin. Begitu juga pada Gambar 5C, partikel-partikel pecahan granula telah menyatu dan tidak terpilin. Pembentukan pilin/ulir tersebut muncul akibat adanya jumlah amilosa bebas yang berlebih di dalam beras analog dan menambah kekerasan beras analog. Menurut Lai dan Kokini (1991), senyawa amilosa bebas yang tidak berinteraksi dengan komponen lain membentuk senyawa baru bisa mengikat partikel-partikel dengan ikatan sekunder. Beras IR 64 yang menjadi kontrol mempunyai kekerasan 4,21 $\mathrm{kg}$ sama dengan kekerasan beras analog pada semua perlakuan kecuali beras analog pada perlakuan suhu ekstrusi $80^{\circ} \mathrm{C}$ dan kadar amilosa adonan $21,72-24,09 \%$ dan beras analog pada suhu ekstrusi $90^{\circ} \mathrm{C}$ dan kadar amilosa $19,35-24,09 \%$.

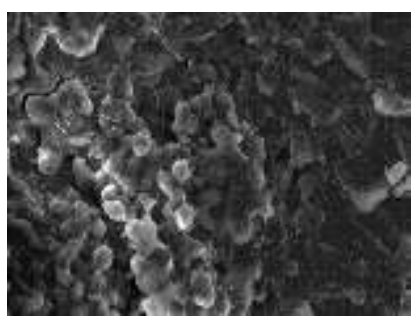

A

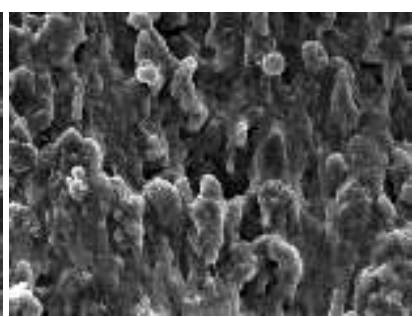

B
Gambar 6. Mikroskopi beras analog (potongan melintang) dengan suhu ekstrusi $70^{\circ} \mathrm{C}$ dan kadar amilosa adonan 16,99\% (A) dan $24,09 \%$ (B) pada Pengamatan SEM dengan perbesaran $750 x$ 
Derajat kristalinitas beras analog menunjukkan korelasi yang positif dengan kekerasan beras analog $(r=0,8 ; \quad P=0,05)$. Peningkatan derajat kristalinitas beras analog meningkatkan keteraturan susunan molekul-molekul senyawa kompleks amilosa-lipid di dalam beras analog sehingga ikatan antar molekul menjadi lebih kuat dan butiran beras analog menjadi lebih keras. Dalam penelitian ini pengukuran karakteristik kristalin dan kekerasan dilakukan berbeda waktu sehingga proses relaksasi makromolekul setelah proses ekstrusi seperti retrogradasi tidak mengindikasikan kondisi sinkron real time pengukuran. Pelaksanaan penelitian rancangan acak lengkap tidak dilaksanakan serentak melainkan bertahap untuk setiap perlakuan. Namun demikian, temuan yang mendukung temuan Budi et al. (2015a) tentang perubahan tipe kristal $\mathrm{A}$ menjadi $\mathrm{V}$ selama proses ekstrusi beras analog serta kenyataan bahwa amilosa bukan menjadi penentu derajat kristalinitas beras analaog untuk bahan berbasis jagung untuk pertama kalinya dipublikasikan dalam penelitian ini.

\section{KESIMPULAN}

Berdasarkan analisis data hasil penelitian dapat disimpulkan bahwa proses ekstrusi panas terhadap bahan berbasis jagung dapat mengubah tipe kristal A dalam matriks bahan menjadi tipe kristal $\mathrm{V}$ dalam matriks beras analog. Peningkatan suhu ekstrusi (dari $70^{\circ} \mathrm{C}$ sampai $90^{\circ} \mathrm{C}$ ) meningkatkan derajat kristalinitas beras analog 1,4 kali (dari 7,98-11,49\% menjadi $12,15-13,61 \%)$ dan kekerasan beras analog 1,5 kali (dari 4,06-4,91 kg menjadi 4,74-8,20 kg). Peningkatan kadar amilosa bahan (dari 16,99\% sampai 24,09\%) meningkatkan kekerasan beras analog 1,4 kali (dari 4,06-4,74 kg menjadi 4,91-8,20 $\mathrm{kg}$ ) tetapi tidak menunjukkan pengaruh yang nyata terhadap derajat kristalinitas. Derajat kristalinitas beras analog berkorelasi positif dengan kekerasan beras analog dengan nilai koefisien korelasi $r=0,8$.

\section{UCAPAN TERIMA KASIH}

Penulis mengucakan banyak terima kasih kepada Direktorat Jenderal Pendidikan Tinggi Kementrian Pendidikan dan Kebudayaan yang telah membiayai penelitian ini lewat skim Hibah Penelitian Unggulan Perguruan Tinggi tahun 2014 dengan nomor SPK 45/IT3.11/LT/2014.

\section{DAFTAR PUSTAKA}

Ajeigbe HA, Ihedioha D, Chikoye D. 2008. Variation in physicochemical properties of seed of selected improved varieties of Cowpea as it relates to industrial utilization of the crop. Afr J Biotechnol 7: 3642-3647.

Alcazar-Alay SC, Meireles MAA. 2015. Physicochemical properties, modifications and applications of starches from different botanical sources. Food Sci Technol 35: 215-236. DOI: 10.1590/1678-457X.6749.

[AOAC] Association of Official Analytical Chemist. 2009. Official Methods of Analysis of AOAC International. Gaithersburg, MD, USA: AOAC International.

Budi FS, Hariyadi P, Budijanto S, Syah D. 2013. Teknologi proses ekstrusi untuk membuat beras analog. Pangan Media Komunikasi Informasi 22: 263-274.

Budi FS, Hariyadi P, Budijanto S, Syah D. 2015a. Effect of dough moisture content and extrusion temperature on degree of gelatinization and crystallinity of rice analogues. J Dev Sus Agr 10: 91-100. DOI: 10.11178/jdsa.10.91.

Budi FS, Hariyadi P, Budijanto S, Syah D. 2015b. Effect of Extrusion Temperature and Moisture Content of Corn Flour on Crystallinity and Hardness of Rice Analogues. Di dalam: Hadiyanto, editor. AIP Conference Proceeding Vol. 1699. International Conference of Chemical and Material Engineering (ICCME) 2015, Sept 29-30, Semarang, Indonesia. Semarang (ID): AIP Publishing LLC.

Budijanto S, Sitanggang AB, Purnomo EH, Yulianti, Widara SS, Karunia A. 2012. Institut Pertanian Bogor. Metode Pengolahan Beras Analog. Paten Indonesia. ID P 00201200463.

Budijanto S, Yuliyanti. 2012. Studi persiapan tepung sorgum (Sorghum bicolor L. Moench) dan aplikasinya pada pembuatan beras analog. J Teknol Pertanian 13: 177-186.

Cuthbert WO, Ray SS, Emmambux MN. 2012. Vamylose structural characteristic. methods of preparation, significance and potential application. Food Rev Int 28: 412-438. DOI: 10.1080/87559129.2012.660718.

De Pilli T, Derossi A, Talja RA, Jouppila K, Severini C. 2011. Study of starch-lipid complexes in model system and real food produced using extrusion-cooking technology. Innov Food Sci Emerg 12: 610-616. DOI: 10.1016/j.ifset.2011. 07.011.

Eckhoff SR, Watson SA. 2009. Corn and Sorghum starches: Production. Di dalam: BeMiller J, Whistler R. Starch: Chemistry and Technology. $3^{\text {rd }}$ Ed. Burlington, USA, Academic Press: 373.

Frost K, Kaminski D, Kirwan G, Lascaris E, Shanks R. 2009. Crystallinity and structure of starch using wide angle X-ray scattering. Carbohyd 
Polym 78: 543-548. DOI: 10.1016/j.carbpol.20 09.05.018.

Gelders GG, Vanderstukken TC, Goesaert H, Delcour JA. 2004. Amylose-lipid complexation: a new fractionation method. Carbohyd Polym 56: 447-458. DOI: 10.1016/j.carbpol.2004.03. 012.

Gragasin MA, Martinez RC. 2015. Development of corn mill for village-level of operation. As J Appl Sci 3: 896-904.

Hoan NV, Mouquet-Rivier C, Treche S. 2010. Effects of starch, lipid and moisture contents on extrusion behavior and extrudate characteristics of rice-based blends prepared with a very-lowcost extruder. J Food Process Eng 33: 519539. DOI: $10.1111 / j .1745-4530.2008 .00288 . x$.

Kang J, Zeng B, Tang S, Wang M, Han X, Zhou C, Yan Q, Liu J, Tan Z. 2017. Effects of Momordica charantia polysaccharide on in vitro ruminal fermentation and cellulolytic bacteria. Ital J Anim Sci 16: 1-8. DOI: 10.1080/18280 51x.2017.1289825.

Kibar EAA, Gonenc I, Us F. 2010. Gelatinization of waxy, normal and high amylose corn starch. GIDA 35: 237-244.

Koide K, Fukushima T, Tomita T, Kuwata T. 1999. Meji Milk Products, Co., Ltd. 1999 Aug 3. Fabricated Rice. US Patent. n,. 5.932.271.

Lai LS, Kokini JL. 1991. Physicochemical change and rheological properties of starch during extrusion (A review). Biotechnol Prog 7: 251266. DOI: $10.1021 / \mathrm{bp00009a009.}$

Liu H, Xie F, Yu L, Chen L, Li L. 2009. Thermal processing of starch-based polymers. Prog Polym Sci 34: 1348-1368. DOI: 10.1016/j.prog polymsci.2009.07.001.

Machmur M, Dahrulsyah, Sawit MH, A, Subagyo Rachman B. 2011. Diversifikasi Pangan Solusi Tepat Membangun Ketahanan Pangan Nasional. Jakarta (ID): Badan Ketahanan Pangan Kementrian Pertanian.

Mahmood T, Turner MA, Stoddard FL. 2007. Comparison of methods for colorimetric amylose determination in cereal grains. Starch/Starke 59: 357-365. DOI: 10.1002/star.2007 00612.
Mishra A, Mishra HN, Rao PS. 2012. Preparation of rice analogues using extrusion technology. Int $\mathrm{J}$ Food Sci Technol 47: 1-9. DOI: 10.1111/j.13652621.2012.03035.x.

Shih F, King J, Daigle K, An HJ, Ali R. 2007. Physicochemical properties of rice starch modified by hydrothermal treatments. Cereal Chem J 84: 527-531. DOI: 10.1094/cchem-845-0527.

Singh N, Kaur L, Sodhi NS, Sekhon KS. 2005. Physicochemical, cooking and textural properties of milled rice from different Indian rice cultivars. Food Chem 89: 253-259. DOI: 10.1016/j.foodchem.2004.02.032.

Terinte N, lbbett R, Schuster KC. 2011. Overview on native cellulose and microcrystalline cellulose I structure studied by X-ray diffraction (WAXD): Comparison between measurement techniques. Lenzinger Berichte 89: 118-131.

Thachil MT, Chouksey MK, Gudipati V. 2014. Amylose-lipid complex formation during extrusion cooking: effect of added lipid type and amylose level on corn-based puffed snacks. Int J Food Sci Technol 49: 309-316. DOI: 10.1111/ ijfs. 12333.

Verma DK, Mohan M, Asthir B. 2013. Physicochemical and cooking characteristics of some promising Basmati genotypes. As J Food AgInd 6: 94-99.

Wang K, Hasjim J, Wu AC, Henry RJ, Gilbert RG. 2014. Variation in amylose fine structure of starches from different botanical sources. J Agr Food Chem 62: 4443-4453.doi: 10.1021/j550 11676.

Xie F, Yu L, Su B, Liu P, Wang J, Liu H, Chen L. 2009. Rheological properties of starches with different amylose/amylopectin ratios. J Cereal Sci 49: 371-377. DOI: 10.1016/j.jcs.2009.01. 002.

Zhuang H, An H, Chen H, Xie Z, Zhao J, Xu X, Jin Z. 2010. Effect of extrusion parameters on physicochmeical properties of hybrid Indica Rice (Type 9718) extrudates. J Food Process Pres 34: 1080-1102. DOI: 10.1111/j.1745-4549.200 9.00439.x. 